\title{
Implementasi Program Rehabilitasi Sosial Rumah Tidak Layak Huni (RS-RTLH) di Kota Tomohon \\ Merry Cintamy Ering, ${ }^{\text {a, }}{ }^{*}$, Wilson Bogar, ${ }^{\text {b, } 2}$, Fitri Mamonto ${ }^{\text {c, } 3}$ \\ ${ }^{a}$ Universitas Negeri Manado, Pascasarjana Ilmu Administrasi Negara, Tomohon Indonesia \\ 1 wilsonbogar@unima.ac.id2; yombog@yahoo.com
}

\section{INF O ARTIKEL}

Diterima 00 April 00

Disetujui 00 Oktober 00

\section{Key word:}

Public Policy,

Policy Implementation,

Social Rehabilitation Program

for Unfit for Living Houses

(RSRTLH) in Tomohon City

\section{A B S T R A C T}

This study aims to determine how the implementation of the Social Rehabilitation Program for Unfit for Living Houses (RS-RTLH) in Tomohon City and the determinant factors in the Social Rehabilitation Program for Unfit for Living Houses (RSRTLH) in Tomohon City using qualitative research methods.The results of research on the implementation of this program show that (1) The number of aid recipients is very minimal because it is limited by budget allocations and the inability of the poor to meet the determined criteria. (2) The implementation of the Program is not yet optimal because there are house construction which have not been completed. This is due to the absence of Standard Operating Procedures (SOP), no social assistants, and a lack of coordination. (3) Monitoring and supervision of the implementation of this Program has not been effective. (4) The budget allocation for this Program is very limited, so it requires self-help from the community. The determinants of the implementation of this program are (1) Communication between the Social Service as the executing agency, village government and beneficiary families is not optimal.(2) The availability of human resources is inadequate (3) Commitment and consistency have not been seen in the implementation of development (4) Policy decisions in the form of orders

\section{INTISARI}

\section{Kata kunci:}

Kebijakan Publik,

Implementasi Kebijakan, Program Rehabilitasi Sosial Rumah Tidak Layak Huni (RS RTLH) di Kota Tomohon.
Penelitian ini bertujuan untuk mengetahui bagaimana Implementasi Program Rehabilitasi Sosial Rumah Tidak Layak Huni (RSRTLH) di Kota Tomohon dan faktor determinan pada Program Rehabilitasi Sosial Rumah Tidak Layak Huni (RSRTLH) di Kota Tomohon dengan menggunakan metode penelitian kualitatif. Hasil penelitan terhadap implementasi program ini menunjukkan bahwa (1) Jumlah penerima bantuan sangat minim karena dibatasi dengan alokasi anggaran serta ketidakmampuan warga miskin dalam memenuhi kriteria yang ditetapkan. (2) Pelaksanaan Program belum optimal karena terdapat pembangunan rumah yang belum selesai. Hal itu disebabkan oleh belum adanya Standar Operasional Prosedur (SOP), tidak ada tenaga pendamping sosial, dan kurangnya koordinasi. (3) Pemantauan dan 
pengawasan terhadap pelaksanaan Program ini belum efektif. (4) Alokasi anggaran untuk Program ini sangat terbatas sehingga membutuhkan swadaya dari masyarakat.Adapun faktor determinan pelaksanaan program ini adalah (1) Komunikasi antara Dinas Sosial selaku instansi pelaksana, pemerintah kelurahan dan keluarga penerima manfaat tidak optimal. (2) Ketersediaan sumber daya manusia belum memadai (3) Komitmen dan konsistensi belum nampak dalam pelaksanaan pembangunan (4) Keputusan kebijakan berupa perintah tidak tersampaikan dengan baik dan tepat yang disebabkan tidak adanya Standar Operasional Prosedur (SOP).

\section{Pendahuluan}

Terpenuhinya semua kebutuhan hidup adalah hak dasar yang diinginkan oleh masyarakat. Meskipun pada realitanya tidak semuanya masyarakat mampu untuk memenuhi kebutuhan hidupnya sebagaimana yang diinginkan dan diharapankan. Salah satu faktor penyebabnya adalah masalah kemiskinan, dimana masyarakat baik yang mempunyai mata pencaharian maupun tidak tetapi tidak mampu memenuhi kebutuhan dasar yang layak bagi kehidupan dirinya.

Dalam Undang-Undang Republik Indonesia Nomor 13 Tahun 2011 tentang Penanganan Fakir Miskin dalam Bab II Pasal 3 disebutkan bahwa Fakir Miskin berhak untuk memperoleh kecukupan pangan, sandang, perumahan, pelayanan kesehatan, pendidikan, perlindungan dan pelayanan sosial melalui jaminan sosial, pemberdayaan sosial, dan rehabilitasi sosial dalam membangun, mengembangkan dan memberdayakan diri dan keluarganya, berhak memperoleh derajat kehidupan yang layak, lingkungan yang sehat, meningkatkan kondisi kesejahteraan yang berkesinambungan serta memperoleh pekerjaan dan kesempatan berusaha [1].

Berdasarkan berita resmi Badan Pusat Statistik pada bulan Juli 2020, presentase penduduk miskin pada Maret 2020 sebesar 9,78 persen, jumlah penduduk miskin pada Maret 2020 sebesar 26,42 juta orang, persentase penduduk miskin di daerah perkotaan pada September 2019 sebesar 6,56 persen, sementara persentase penduduk miskin di daerah pedesaan pada September 2019 sebesar 12,60 persen, jumlah penduduk miskin Maret 2020 di daerah perkotaan naik sebanyak 1,3 juta orang, garis kemiskinan pada Maret 2020 tercatat sebesar Rp. 454.652,kapita/bulan. Pada Maret 2020, secara rata-rata rumah tangga miskin di Indonesia memiliki 4,66 orang anggota rumah tangga. Dengan demikian, besarnya garis kemiskinan per rumah tangga ahun (Nama Penulis). All Right Reserved

miskin secara rata-rata adalah sebesar $\mathrm{Rp}$. 2.118.678,-/rumah tangga miskin/bulan [2].

Undang-Undang Nomor 11 Tahun 2009 tentang Kesejahteraan Sosial merupakan arah kebijakan penyelenggaraan kesejahteraan sosial yang terpadu dan berkelanjutan yang dilakukan oleh pemerintah baik pusat maupun pemerintah daerah dan masyarakat dalam bentuk pelayanan sosial guna memenuhi kebutuhan dasar setiap warga negara diantaranya rehabilitasi sosial. Rehabilitasi sosial adalah proses refungsionalisasi dan pengembangan untuk memungkinkan seseorang mampu melaksanakan fungsi sosialnya secara wajar dalam kehidupan masyarakat. Rehabilitasi sosial dimaksudkan untuk memulihkan dan mengembangkan kemampuan seseorang yang mengalami disfungsi sosial agar dapat melaksanakan fungsi sosialnya secara wajar. Rehabilitasi sosial diberikan dalam berbagai bentuk diantaranya motivasi dan diagnosis psikososial, pelayanan aksebilitas, bantuan dan asistensi sosial. Salah satu indikator penting dalam penyelenggaraan kesejahteraan sosial sebagai bagian dari penanggulangan kemiskinan yaitu penyediaan akses pelayanan perumahan dan pemukiman [3].

Kementerian Pekerjaan Umum dan Perumahan Rakyat (PUPR) Republik Indonesia menyatakan, saat ini masih ada sebesar 3,4 juta rumah yang tidak layak huni [3]. Potret seperti ini menunjukkan betapa rentannya permasalahan sosial yang akan muncul di masyarakat apabila pemenuhan kebutuhan rumah yang layak huni ini tidak dapat diatasi. Oleh karena itu, perlu adanya perhatian yang serius dari pemerintah terkait dengan rumah tidak layak huni.

Berbagai upaya telah dilakukan pemerintah sebagai penyelenggara pemerintahan melalui program-program yang bertujuan untuk menanggulangi masalah kemiskinan, dengan memberikan pemberdayaan secara berkelanjutan. Diantaranya adalah Program Rehabilitasi Sosial 
Rumah Tidak Layak Huni (RS RTLH) melalui Kementrian Sosial Republik Indonesia

Program Rehabilitasi Sosial Rumah Tidak Layak Huni tidak hanya berfokus pada aspek fisik rumah saja, tetapi jauh lebih penting adalah bagaimana membangun kapasitas kelompok fakir miskin untuk memahami dan menyadari bahwa pentingnya tempat tinggal yang layak huni dan aspek sosial dalam lingkungan keluarga yang diharapkan akan memupuk rasa kesetiakwanan sosial dan semangat gotong royong di tengahtengah masyarakat yang sudah mulai memudar. Program ini diharapkan akan menjawab kebutuhan fakir miskin untuk memperoleh kecukupan perumahan yang layak huni, serta menjadi suatu bentuk motivasi dan rangsangan bagi masyarakat miskin penerima manfaat untuk lebih mengembangkan lagi taraf hidup sosial guna terhindar dari permasalahan-permasalahan sosial lainnya.

Pelaksanaan Program Rehabilitasi Sosial Rumah Tidak Layak Huni di Kota Tomohon mengacuh pada petunjuk pelaksaksanaan sesuai Peraturan Menteri Sosial Nomor 20 Tahun 2017 yang kemudian dibuatkan Surat Keputusan Walikota Tomohon tentang Penetapan Penerima Bantuan Rehabilitasi Sosial Rumah Tidak Layak Huni Kota Tomohon. Program ini dilaksanakan sejak tahun 2017 dan berkelanjutan setiap tahun dengan jumlah penerima bantuan setiap tahunnya berjumlah 5 Keluarga

$$
\text { Penerima Manfaat (KPM) [4]. }
$$

Berdasarkan observasi dan wawancara yang dilakukan oleh peneliti, ada berbagai alasan dan keterangan yang disampaikan oleh masyarakat terkait dengan pelaksanaan program ini diantaranya : masih ada masyarakat yang belum mengetahui adanya program Rehabilitasi Sosial Rumah Tidak Layak Huni, belum semua masyarakat yang tergolong miskin dan memiliki rumah yang tidak layak huni tersentuh dengan program ini. Disamping itu juga dalam pelaksanaannya masih dijumpai berbagai permasalahan dan hambatan yang tidak sesuai dengan petunjuk teknis pelaksanaannya hingga saat ini renovasi/pembangunan rumah belum selesai dilaksanakan, sehingga hingga tahun 2020 ini keluarga penerima manfaat belum bisa menempati rumah tersebut dan merasakan manfaat program ini secara baik. Permasalahan lainnya terkait dengan pelaksanaan pembangunan adalah lemahnya sistem pengawasan yang dilaksanakan oleh instansi terkait dalam hal ini Dinas Sosial.
Berdasarkan latar belakang permasalahan di atas, maka peneliti melakukan penelitian dengan Judul Implementasi Program Rehabilitasi Sosial Rumah Tidak Layak Huni (RSRTLH) di Kota Tomohon.

\section{a. Rumusan Masalah}

Berdasarkan fenomena permasalahan yang sudah diuraikan dalam latar belakang maka yang menjadi rumusan masalah dalam penelitian ini adalah :

1. Bagaimana Implementasi Program Rehabilitasi Sosial Rumah Tidak Layak Huni (RS-RTLH) di Kota Tomohon?

2. Apa saja faktor determinan pada rogram Rehabilitasi Sosial Rumah

\section{b. Tujuan Penelitian}

Tujuan yang hendak dicapai dalam penelitian ini adalah untuk :

1. Mengetahui bagaimana implementasi program Rehabilitasi Sosial Rumah Tidak Layak Huni di Kota Tomohon.

2. Mengetahui faktor determinan pada Program Rehabilitasi Sosial Rumah Tidak Layak Huni di Kota Tomohon.

\section{Metode Penelitian}

Metode yang digunakan dalam penelitian ini adalah metode penelitian deskriptif dengan pendekatan kualitatif. Menurut Meleong metode penelitian deskriptif dengan pendekatan kualitatif adalah penelitian yang bermaksud untuk memahami fenomena tentang apa yang dialami oleh subjek penelitian seperti pelaku, persepsi, motivasi, dan tindakan secara holistik dan dengan cara deskriptif dalam bentuk kata-kata dan bahasa sesuai konteks yang alamiah. Sama halnya dengan yang dikemukakan oleh Bodgan dan Taylor dalam Meleong, bahwa metode penelitian deskriptif dengan pendekatan kualitatif merupakan prosedur penelitian yang menghasilkan data deskriptif berupa kata-kata tertulis maupun lisan dari orang-orang dan perilaku yang diamati [5].

\section{c. Fokus Penelitian}

Penelitian ini secara khusus akan difokuskan pada 2 pembahasan utama yaitu :

1. Bagaimana implementasi program rehabilitasi sosial rumah tidak layak huni di Kota Tomohon dengan indikator-indikator berupa mekanisme pengusulan, pelaksanaan kegiatan dan sistem pemantauan dan pengawasan serta penganggaran.

2. Apa saja faktor determinan pada program Rehabilitasi Sosial Rumah Tidak Layak Huni 
(RS-RTLH) di Kota Tomohon yang dilihat dari segi komunikasi, sumber daya, disposisi dan struktur birokrasi.

\section{d. Tinjauan Pustaka}

Seperti yang dirangkum Irfan Islamy tentang pengertian kebijakan publik diantaranya George Edward III dan Sharkansky yang menyebutkan "what goverment say and do, or not to do" bahwa kebijakan publik adalah apa yang dinyatakan dan dilakukan atau tidak dilakukan oleh pemerintah yang dapat ditetapkan dalam peraturan-peraturan perundang-undangan atau dalam policy statement yang berbentuk pidatopidato atau wacana yang diungkapkan pejabat politik dan pejabat pemerintah yang segera ditindaklanjuti dengan programprogram dan tindakan pemerintah "It is the goals or purposes of goverments programs" [6].Suatu kebijakan harus diimplementasikan untuk memastikan terlaksananya suatu tindakan atau rencana. Sukses tidaknya suatu kebijakan tergantung pada implementasinya, sehingga memiliki peran yang terpenting dalam pelaksanaannya. Meter dan Horn dalam Agustino mendefinisikan implementasi kebijakan sebagai tindakantindakan yang

dilakukan baik oleh individuindividu/pejabat atau kelompok pemerintah atau swasta yang diarahkan pada tercapainya tujuan-tujuan yang telah digariskan dalam keputusan kebijakan. Keberhasilan suatu implementasi kebijakan dapat diukur atau dilihat dari proses dan pencapaian tujuan akhir yakni tercapai atau tidaknya tujuantujuan yang ingin dicapai. Pada dasarnya implementasi kebijakan adalah tindakantindakan. Tindakan tersebut dilakukan oleh pemerintah untuk mencapai suatu tujuan yang dirumuskan lewat keputusan atau ketetapan [7].

Batasan-batasan dalam implementasi kebijakan sebagaimana yang dikemukakan Edward III "Policy implementation is the stage of policy making between the establishment of policy, such as the passage of legislative act, the issuing of an axecutive order, the handing down of a judical decesion, or the promulgation of a regulatiory rule and the consequences of the policy for the people whom it effects". Studi tentang implementasi kebijakan dipandang krusial bagi administrasi publik dan kebijakan publik. Implementasi kebijakan merupakan tahap pembuatan kebijakan bagi masyarakat yang dipengaruhinya antara pembentukan dan konsekuensi kebijakan. Meskipun suatu kebijakan sudah dilaksanakan dengan baik bisa saja mengalami kegagalan yang disebabkan oleh pelaksanaan yang tidak tepat, tidak mencapai sasaran dan tidak dapat mengurangi permasalahan yang menajadi dasar dibuatnya sutu kebijakan tersebut [9].

Dalam buku Winarno model implementasi yang dikembangkan oleh Edward III disebut dengan Direct and Impact on Implementation, terdapat empat variabel penentu keberhasilan suatu implementasi kebijakan antara lain : (1) Komunikasi (comunication), (2) Sumber Daya (resource) (3) Disposisi (disposition), (4) Struktur Birokrasi (bureaucratic structure) [10]. Model implementasi kebijakan yang dikemukakan oleh Edward III dapat dilihat pada gambar di bawah ini :

Model Implementasi yang dikemukakan oleh Edward III digambarkan bahwa implementasi kebijakan berjalan secara linier saling berhubungan satu dengan yang lainnya. Proses ini menunjukkan suatu abstraksi atau performansi suatu kebijakan yang diupayakan untuk meraih kinerja implementasi kebijakan publik dalam hubungan antar masing-masing variabel.

1. Komunikasi (comunication) Komunikasi merupakan sarana untuk menghubungkan tujuan dan sasaran kebijakan kepada kelompok sasaran agar mengurangi distorsi implementasi. Suatu kebijakan harus dikomunikasikan baik kepada organisasi maupun kepada publik, serta dilakukan dengan sikap dan tanggap dari pihak-pihak yang terlibat termasuk didalamnya struktur organisasi sebagai pelaku kebijakan. Implementasi akan berjalan secara efektif jika ukuran dan tujuan kebijakan dipahami oleh setiap individu pelaksana kebijakan. Ukuran dan tujuan yang jelas perlu dikomunikasikan secara tepat dan benar agar ada keseragaman dan konsistensi dalam mencapai tujuan kebijakan tersebut. Kebijakan yang tidak dikomunikasikan secara baik dan benar dapat menyebabkan ketidakjelasan dan bahkan tidak mengerti dengan maksud dan tujuan kebijakan apalagi jika proses pelaksanaan yang tidak dikomunikasikan dengan jelas dapat menyebabkan kebingungan dan mendapatkan hasil yang tidak optimal. Disisi lain komunikasi dapat juga melahirkan interpretasi yang berbeda-beda dari publik sehingga dapat tersebarluaskan dan digunakan untuk kepentingankepentingan tertentu.

2. Sumber daya (resource)

Sumber daya menjadi faktor penting dalam implementasi kebijakan. Sumber daya lebih mengarah kepada manusia sebagai pelaku kebijakan. Dengan ketersediaan sumber daya pendukung yang memadai serta kecakapan pelaksanan kebijakan maka implementasi akan berjalan dengan efektif. Bagaimanapun jelasnya 
kebijakan dikomunikasikan jika personel atau sumber daya manusia yang bertanggungjawab kurang maka hal tersebut menjadi permasalahan. Komponen sumber daya meliputi jumlah personel atau staf yang didukung oleh keahlian, informasi yang relevan dalam memenuhi sumber-sumber terkait dalam pelaksanaan program, serta kewenangan yang memberi jaminan kebijakan terlaksana sebagaimana harapan dan yang penting juga yaitu fasilitas-fasilitas pendukung yang akan digunakan dalam menjalankan program misalnya sumber dana dan sarana prasarana.

\section{Disposisi (disposition)}

Disposisi merupakan suatu kesediaan dan komitmen untuk melaksanakan suatu kebijakan. Di dalamnya juga terkandung watak dan karakteristik dari pembuat kebijakan seperti jujur dan demokratis. Salah satu faktor yang mempengaruhi efektivitas kebijakan adalah sikap implementor. Jika implementor setuju dengan tahapan dan proses pelaksanaan kebijakan maka mereka akan melaksanakannya dengan senang hati. Sebaliknya, jika suatu kebijakan yang di dalamnya proses dan tahapan yang tidak disetujui oleh implementor maka akan menghambat proses implementasi dan dapat menyebabkan permasalahan-permasalahan di lapangan. Dukungan dari pejabat atau pimpinan juga sangat mempengaruhi pelaksanaan kebijakan. Dukungan dimaksud yakni dengan menempatkan suatu kebijakan sebagai prioritas yang diikuti dengan penyediaan dana yang cukup, menempatkan orangorang yang benar-benar mendukung pelaksanaan program, memperhatikan kearifan lokal seperti agama, suku, adat, jenis kelamin, serta karakter. Dan yang penting juga adalah memberikan kesejahteraan baik berupa insentif atau dalam bentuk lainnya bagi pelaksana kebijakan sehingga mereka dapat bekerja secara total dalam menjalankan kebijakan tersebut.

4. Struktur birokrasi(bereaucraticstructure)

Struktur birokrasi memiliki pengaruh yang signifikan dalam proses implementasi kebijakan. Struktur organisasi berkenaan dengan kesesuaian organisasi birokrasi yang menjadi penyelenggaran implementasi kebijakan publik [8].

Edward III juga menegaskan bahwa yang menjadi permasalahan dalam implementasi kebijakan publik adalah " Lack of attention to implementation, without effective implementation, the decission of policy maker will not be carried out successfully". Bagi para pelaksana kebijakan harus mengetahui apa yang harus dilakukan, hal itu menjadi syarat utama dalam mewujudkan implementasi kebijakan publik yang efektif. Keputusan kebijakan berupa perintah harus tersampaikan kepada pelaku kebijakan secara tepat, didukung pula dengan ketersediaan sumber daya yang cermat, konsisten, dan berkomitmen [9].

\section{Hasil dan Pembahasan}

Adapun hasil penelitian tentang implementasi program rehabilitasi sosial rumah tidak layak huni di Kota Tomohon adalah sebagai berikut :

1. Mekanisme Pengusulan Calon penerima bantuan melalui program RS-RTLH di Kota

Tomohon ditetapkan dengan Surat Keputusan Walikota Tomohon, dimana dalam surat keputusan tersebut menetapkan sejumlah keluarga yang dianggap layak untuk menerima bantuan berdasarkan hasil verifikasi yang dilakukan oleh Dinas

Sosial Kota Tomohon, dengan memastikan bahwa warga tersebut termasuk dalam Data Terpadu Keluarga Sejahtera (DTKS). Namun dalam melaksanakan setiap tahapan implementasi program RS-RTLH di Kota Tomohon ini, tidak diatur dengan Standar Operasional Prosedur (SOP) yang merupakan suatu prosedur atau aktifitas terencana yang memungkinkan para pelaksana kebijakan untuk melaksanakan kegiatan-kegiatan sesuai dengan standar yang ditetapkan. Menurut George Edward III, Standar Operasional prosedur (SOP) merupakan salah satu karakteristik yang dapat mendongkrak kinerja struktur birokrasi dalam melaksanakan suatu kebijakan [7].

Seluruh warga miskin yang memiliki rumah tidak layak huni belum semuanya dapat diakomodir untuk menerima bantuan. Hal tersebut disebabkan karena keterbatasan jumlah unit yang dianggarkan sehingga berdasarkan jumlah tersebut maka pemerintah kelurahan mengajukan calon penerima yang disesuaikan dengan kuota yang ada. Dalam penelitian ini juga didapati bahwa sebagian warga tidak dapat memenuhi kriteria sebagai calon penerima bantuan. Yang paling menonjol yaitu terkait dengan legalitas kepemilikan lahan untuk pembangunan rumah, yang pada umumnya belum mempunyailahan milik dan atas nama sendiri 2 . Pelaksanaan Kegiatan Program Rehabilitasi Sosial Rumah Tidak Layak Huni di Kota Tomohon dilaksanakan oleh Dinas Sosial Daerah Kota Tomohon. Dalam Dokumen Pelaksanaan Anggaran bantuan ini diberikan dalam bentuk bahan-bahan bangunan yang secara rinci memuat bahan-bahan apa saja yang akan dipakai dalam pembangunan rumah. Pada awalnya baik keluarga maupun pemerintah kelurahan 
berpemahaman bahwa program ini adalah bantuan rumah yang diserahkan setelah selesai pembangunan, namun pada pelaksanaannya oleh Dinas Sosial hanya sampai pada penyerahan bahan-bahan bangunan, untuk selanjutnya dilakukan oleh keluarga penerima manfaat.

Selaku pemerintah kelurahan diharapkan dapat menjadi motor dalam pelaksanaan program ini, namun pada kenyataannya pemerintah kelurahan merasa tidak terlalu dilibatkan karena kurangnya koordinasi yang dilakukan oleh Dinas Sosial sebagai penanggungjawab. Komunikasi dalam bentuk sosialisasi tidak pernah dilaksanakan sehingga selain menimbulkan pemahaman yang berbeda tapi juga pelaksanaan kegiatan ini tidak terkontrol selama proses pembangunananya. Dalam pelaksanaannya belum sepenuhnya ada swadaya dari masyarakat, karena keengganan dari keluarga penerima manfaat itu sendiri dalam menggerakkan lingkungan sekitar untuk bergotong-royong. Salah satu penyebab kurangnya koordinasi dari para pelaksana kebijakan adalah karena tidak tersedianya tenaga pendamping sosial sebagaimana amanat Peraturan Menteri Sosial Nomor 20 Tahun 2017 tentang Rehabilitasi Sosial Rumah Tidak Layak huni dan sarana Prasarana Lingkungan pada Pasal 16 yang dilihat dari tugasnya memegang peranan yang sangat penting dalam pelaksanaan kegiatan. Keterbatasan sumberdaya yang tidak didukung dengan anggaran yang memadai akan sangat memengaruhi kinerja.

\section{Pemantauan dan Pengawasan Dalam} pelaksanaan program Rehabilitasi Sosial Rumah Tidak Layak Huni (RS-RTLH) di Kota Tomohon berdasarkan hasil penelitian menunjukkan bahwa pemantauan dan pengawasan yang dilakukan sangat kurang efektif. Kegiatan pemantauan terhadap pelaksanaan pembangunan tidak secara rutin dilakukan, hal tersebut turut dirasakan oleh pemerintah kelurahan dimana selaku penanggungjawab wilayah kelurahan merasa kurang dilibatkan dalam melaksanakan program ini. Jika ada koordinasi yang baik oleh Dinas Sosial kepada pemerintah kelurahan maka dari pihak kelurahan pun akan proaktif dalam mempercepat mendorong pelaksanaan pembangunan serta secara rutin melaporkan perkembangan pembangunan rumah yang ada.

Perihal kurangnya pemantauan dan pengawasan yang dilakukan oleh Dinas Sosial, hal tersebut dibenarkan oleh pihak Dinas Sosial dengan alasan bahwa untuk pelaksanaan pembangunan sudah diserahkan langsung kepada pihak keluarga penerima manfaat, sehingga membuka kesempatan yang sebesar-besarnya bagi keluarga jika hendak pemberbesar dan memperlebar bangunan seperti yang terlihat dalam gambar di atas. Hal tersebut berdampak pada ketidakmampuan KPM dalam memenuhi tambahan biaya pembangunan yang menjadi salah satu penyebab hingga saat ini pembangunan rumah melalui bantuan Program RS-RTLH tak kunjung selesai. Program Rehabilitasi Sosial Rumah Tidak Layak Huni (RS-RTLH) di Kota Tomohon tidak ada pendamping sosial, padahal pendamping sosial memiliki peranan yang penting dalam pelaksanaan kegiatan di lapangan. Sehubungan dengan tidak adanya pendamping sosial maka untuk tugas dan tanggungjawab dalam pelaksanaan program ini mulai dari tahap pengajuan usulan sampai dengan pembangunan dan pelaporan akhir dilakukan langsung oleh pegawai Dinas Sosial yang ada sesuai dengan tugas pokok dan fungsinya. Kenyataan di lapangan bahwa ada rumah yang hingga saat ini belum dirasakan manfaatnya oleh KPM, pembangunan belum selesai namun tidak lagi di bawah pengawasan dari Dinas Sosial. Dapat dikatakan bahwa pada akhirnya program ini akan mubasir dan tidak menjawab kebutuhan dari KPM untuk dapat memiliki rumah yang layak huni. 4. Penganggaran Pada Program Rehabilitasi Sosial Rumah Tidak Layak Huni (RSRTLH) di Kota Tomohon dibiayai oleh APBD. Ada juga pembiayaan dari APBN tapi sudah sejak tahun 2017, dan pada tahun 20182019 sudah tidak ada lagi. Dari pagu anggaran yang sangat terbatas diupayakan untuk menganggarkan bantuan bagi 5 keluarga miskin yang tidak memiliki rumah layak huni dengan masing-masing Rp. 15.000.000 (lima belas juta rupiah) untuk tahun 2019. Dilihat dari jumlah anggaran yang ada memang masih sangat minim untuk ukuran membangun unit rumah yang layak huni. Sehingga anggaran yang dialokasikan melalui Dinas Sosial tersebut tidak mencukupi untuk membangun sampai pada tahap akhir, sehingga membutuhkan swadaya dari keluarga maupun masyarakat sekitar. Anggaran lainnya seperti kesejahteraan bagi para pelaksana kebijakan tidak dialokasikan, sehingga mempengaruhi kinerja dari para pelaksana kebijakan. Dengan tidak dialokasikan anggaran maka Dinas Sosial juga tidak merekrut atau menyiapkan pendamping sosial atau tim teknis yang khusus untuk memantau dan mengontrol perkembangan pembangunan rumah yang ada.

Berdasarkan hasil penelitian, maka faktor-

faktor dalam implementasi kebijakan seperti komunikasi, sumber daya, disposisi dan struktur 
organisasi semuanya masih memiliki kekurangan dan kelemahan, yang menyebabkan implementasi Program Rehabilitasi Sosial Rumah Tidak Layak Huni (RSRTLH) di Kota Tomohon belum berjalan dengan baik. Kurangnya komunikasi antara Dinas Sosial, pemerintah kelurahan, dan masyarakat penerima manfaat menimbulkan persepsi yang berbeda-beda tentang Program RSRTLH. Hal itu pun harus didukung dengan ketersediaan sumber daya baik manusia sebagai pelaksana kebijakan maupun dana sebagai pendukung terlaksananya program RS-RTLH di Kota Tomohon. Karena sebagaimana baiknya program ini diketahui oleh masyarakat namun jika tidak didukung dengan sumber daya maka tidak akan berjalan dengan baik. Begitupun halnya dengan sikap dan karakter dari implementor yang harus selaras dengan masyarakat penerima manfaat, karena sebagaimana didapati bahwa keluarga belum bisa menempati karena pembangunannya yang belum selesai bahkan meskipun sudah ditempati namun tetap dalam kondisi yang belum layak huni. Dukungan terhadap tenaga pelaksana kebijakan juga sangat penting yaitu berupa dana yang dialokasikan untuk menunjang operasional seperti insentif, sarana dan prasarana penunjang.

\section{KESIMPULAN}

Dari hasil penelitian yang sudah diuraikan sebelumnya serta telah dibahas dan dianalisis, maka penelitian Implementasi Program Rehabilitasi Sosial Rumah Tidak Layak Huni (RSRTLH) di Kota Tomohon dapat disimpulkan sebagai berikut :

(1) Kebijakan pemerintah untuk menanggulangi kemiskinan melalui Program Rehabilitasi Sosial Rumah Tidak Layak Huni (RS-RTLH) telah dilaksanakan di Kota Tomohon dengan jumlah penerima bantuan yang sangat minim sesuai serta ketidakmampuan warga miskin dalam memenuhi kriteria yang ditetapkan.

(2) Pelaksanaan Program Rehabilitasi Sosial Rumah Tidak Layak Huni (RSRTLH) di Kota Tomohon belum optimal.

(3) Pemantauan dan pengawasan terhadap pelaksanaan Program Rehabilitasi Sosial Rumah Tidak Layak Huni (RS-RTLH) di Kota Tomohon belum efektif.

(4) Alokasi anggaran untuk Program Rehabi litasi Sosial Rumah Tidak Layak Huni (RSRTLH) di Kota Tomohon sangat terbatas sehingga membutuhkan swadaya dari masyarakat.
Sementara yang menjadi Faktor determinan terhadap implementasi program ini yaintu : (

(1) Komunikasi tidak optimal.

(2) Ketersediaan sumber daya manusia sebagai pelaksana kebijakan Program Rehabilitasi Sosial Rumah Tidak Layak Huni (RS-RTLH) belum memadai,

(3) Komitmen dan konsistensi belum nampak dalam pelaksanaan pembangunan,

(4) Keputusan kebijakan berupa perintah tidak tersampaikan dengan baik dan tepat.

\section{Referensi}

[1] Undang - Undang Republik Indonesia Nomor 13 Tahun 2011 tentang Penanganan Fakir Miskin

[2] Badan Pusat Statistik, "Presentase Penduduk Miskin Maret 2020 naik menjadi 9,78 persen”. 2020 (Diakses tanggal 21 Juli 2020)

[3] Yovanda, Yanuar. "Sindo News. 34 juta rumah di Indonesia masih tak layak huni" SindoNews.com (Diakses tanggal 26 Maret 2019)

[4] Kementerian Sosial RI. Peraturan Menteri Sosial Nomor Remaja Rosdakarya. 2018.

[5] I. Islamy. "Prinsip-prinsip perumusan kebijakan Negara," Jakarta : PT. Bumi Aksara (1998).

[6] Agustino."Dasar - Dasar Kebijakan Publik," Bandung : Alfabeta. 2008.

[7] J. Mantiri and C. M. Siwi, "PERAN PEMERINTAH SEBAGAI KUNCI UTAMA PENGELOLAAN DANA DESA DI DESA DULUMAI KECAMATAN PAMO PUSELEMBA KABUPATEN POSO PROPINSI SULAWESI

[8] TENGAH," J. Civ. Educ. Media Kaji. Pancasila dan Kewarganegaraan, 2018.

[9] Edward III, George C. "Implementing Public Policy. Washington DC," USA: Congresstional Quartes Press.

[10] 20 Tahun 2017 tentang Rehabilitasi Sosial Rumah Tidak Layak Huni dan Sarana Prasaran Lingkungan.

[11] Meleong. "Metodologi Penelitian Kualitatif. Edisi Revisi," Bandung : PT. 1980. 
Merry Ering, Wilson Boga dan Fitri Mamonto, / Jurnal Administro Vol. 2 No. 2 (2020) pp: 32 -39

[12] Winarno, B. 2007. Kebijakan Publik Teori dan Proses. Togyakarta : Media Persada. 